\title{
УOBОЗНАВСТВO. NITEPATУРОВНАВСТВO
}

\author{
УДК 821.161.2:7.034.7Братковський Д. \\ DOI https://doi.org/10.24919/2308-4863/35-3-13
}

\author{
Анастасія КАТЮЖИНСЬКА, \\ orcid.org/0000-0003-4738-434X \\ студентка IV курсу \\ Інституту філології \\ Київського наџіонального університету імені Тараса Шевченка \\ (Киї, Україна) nastya16k21@gmail.com
}

\section{ІНТЕРПРЕТАЦЙНА МОДЕЛЬ КОНЦЕПТУ ОСОБИСТОСТІ У ТВОРЧОСТІ ДАНИЛА БРАТКОВСЬКОГО}

\begin{abstract}
У статті досліджено інтерпретаиійну модель конщепту особистості у творчості Данила Братковського. На основі иілісного аналізу життєвого та творчого шляху письменника обтрунтовано особливості втілення барокової художньої образності та світогляду. Особливу увагу звернено на обгрунтування барокового характеру інтерпретаційної моделі концепту особистості, в основу якої покладено синтез антропоцентричного і теоцентричного світоглядів. Виокремлено основні складники концепту особистості, проаналізовано особливості їхної репрезентаиії у збіриі «Світ, по частинах розглянутий».

Наукова новизна дослідження полягає в застосуванні сучасної методологічної парадигми, яка спирається на міждисциплінарний підхід, заснований на поєднанні історико-літературного методу, а отже, основоположними є праці дослідників української літератури епохи Бароко (В. Крекотня, Л. Ушкалова, В. Шевчука та ін.), елементів герменевтичного методу, із методологічною парадигмою історії та філософії.

У збіриі Данила Братковського «Світ, по частинах розглянутий» репрезентовано інтерпретаційну модель кониепту особистості, засновану на синтезі антропоцентричного і теоиентричного світоглядів, що свідчить про ї̈ бароковий характер. Письменник апелює до концеппуу свободи, розрізняючи його національний $і$ особистий складники. Антропочентризм у концептуальній картині світу Данила Братковського репрезентовано передусім через осмислення ідеї свободи, позначеної патріотизмом. Національна самоідентифікація, готовність до боротьби є визначальними характеристиками в авторській інтерпретації історичних подій $і$ сприйняття тогочасного суспільства. Теочентричне спрямування світоглядних орієнтирів особистості реалізується через авторське розуміння віри, зокрема вірність православ 'ю протягом життя, заперечення унії. Основними складниками концепту особистості, репрезентованого у творчості Данила Братковського, визначено шляхетське походження письменника, виховання у православній родині, тогочасні історичні подї та становище украӥнського народу, освіта в Києво-Могилянській академії й університетах Західної Європи, а також барокова світоглядна парадигма, щзо вплинуло на поєднання європейських і національних традицій у творчій спадщчині мития.
\end{abstract}

Ключові слова: концепт особистості, украӥнське літературне Бароко, антропоцентризм, теоцентризм, Данило Братковський, «Світ, по частинах розглянутий».

Anastasiia KATYUZHYNSKA,
orcid.org/0000-0003-4738-434X orcid.org/0000-0003-4738-434X
Fourth-Year Student Institute of Philology

of Taras Shevchenko National University of Kyiv (Kyiv, Ukraine)nastya16k21@gmail.com

\section{THE INTERPRETATIVE MODEL OF THE CONCEPT OF PERSONALITY IN THE CREATIVITY OF DANYLO BRATKOVSKY}

The aim of this article is to investigate the interpretive model of the concept of personality in the works of Danylo Bratkovsky. Based on a holistic analysis of the life and creativity of the writer the peculiarities of the representation of baroque artistic imagery and worldview are substantiated. Particular attention is paid to the substantiation of the baroque nature of the interpretive model of the concept of personality, which is based on the synthesis of anthropocentric and theocentric worldviews. The main components of the concept of personality are singled out, the peculiarities of their representation in the collection "The world, considered in parts" are analyzed.

The scientific novelty of the article consists in the application of a modern methodological paradigm based on an interdisciplinary approach based on a synthesis of historical-literary method, and, therefore, the works of researchers 
of the Baroque epoch literature (V. Krekoten, L. Ushkalov, V. Shevchuk, etc.) are fundamental, elements of hermeneutic method, with a methodological paradigm of history and philosophy.

The collection "The world, considered in parts" of Danylo Bratkovsky represents the interpretive model of the concept of personality based on the synthesis of anthropocentric and theocentric worldviews, which testifies to its baroque character. The writer appeals to the concept of freedom, distinguishing its national and personal components. Anthropocentrism in the conceptual picture of the world of Danylo Bratkovsky is represented primarily through the understanding of the idea of freedom, marked by patriotism. National self-identification, readiness to fight are the defining characteristics of the author's interpretation of historical events and perception of society. The theocentric orientation of the worldview of the personality is realized through the author's understanding of the faith, in particular fidelity to Orthodoxy throughout life, denial of the Union. The main components of the concept of personality represented in the works of Danylo Bratkovsky are the noble origin of the writer, upbringing in the Orthodox family, historical events and the situation of the Ukrainian people, education at the Kyiv-Mohyla Academy and universities of Western Europe, and the Baroque worldview, which influenced the synthesis of European and national traditions in the artist's creative heritage.

Key words: concept of personality, Ukrainian literary Baroque, anthropocentrism, theocentrism, Danylo Bratkovsky, "The world, in parts considered".

Постановка проблеми. В епоху Бароко формується новий світогляд, який характеризується актуалізацією філософської проблеми «людина - світ». Твориться цілком нова інтерпретаційна модель особистості, що яскраво репрезентовано у світоглядно-художніх концепціях письменників, зокрема Данила Братковського. Власне, аналіз життя та творчості митця свідчить, що сутність інтерпретаційної моделі концепту особистості має цілком бароковий характер і відзначається чітко вираженими складниками.

Аналіз досліджень. Різні аспекти творчості Д. Братковського ставали предметом зацікавлення таких дослідників української літератури епохи Бароко, як В. Крекотень, В. Шевчук, Л. Ушкалов, О. Бай, О. Турчин, О. Яковина, Р. Радишевський, С. Сухарєва та ін. Окрім того, життєвий шлях письменника проаналізовано у працях В. Антоновича, В. Липинського, М. Возняка, М. Драгоманова та ін. На філософсько-історичному складнику творчості Д. Братковського зосереджували увагу Д. Кулиняк, М. Довбищенко, П. Кралюк та ін., однак актуальним залишається цілісний аналіз інтерпретаційної моделі концепту особистості у творчості письменника 3 огляду на застосування сучасної методологічної парадигми 3 апелюванням до міждисциплінарного підходу.

Мета статті - дослідити особливості інтерпретаційної моделі концепту особистості у творчості Данила Братковського, звернувши увагу на репрезентацію в ній художньої образності та світогляду епохи Бароко; виокремити основні складники концепту особистості на основі аналізу біографії та творчої спадщини письменника, представлених у збірці «Світ, по частинах розглянутий».

Виклад основного матеріалу. На формування концепту особистості, репрезентованого у творчості Данила Братковського, мали вплив чинники, які стали складниками його інтерпретаційної моделі. Визначальним був бароковий характер, котрий позначився на світогляді письменника. Так, народився Данило Братковський близько 1642 p. у шляхетській православній родині на Волині. В. Шевчук про рід Братковських пише: «Братковські належали до давньої української шляхти, яка жила в Брацлавськім і Волинськім воєводствах. Цей рід, на противагу іншим, завжди тримався міцно православ'я та своєї народності й був тісно зв'язаний з одним із визначальних культурних осередків в Україні у XVII ст. - з Луцьким православним братством. Цікаво, що його батько Богдан у 1675-1677 був старостою братства... Данило був вихований змалку у дусі “твердого благочестя”» (Шевчук, 2004: 5). На такій визначальній рисі роду Братковських, як вірність православ'ю наголошував також М. Возняк: «Братковські замітні тим, що трималися міцно православної віри й української народності тоді, коли інші українські шляхетські роди на Правобережній Україні щораз більше польщилися» (Возняк, 1994: 54). Власне, саме народження в родині представників православної шляхти вплинуло на формування таких складників концепту особистості, як авторське ставлення до шляхти та православ'я, що пізніше буде представлено у творчості, передусім збірці «Світ, по частинах розглянутий».

Варто зазначити, що конфесійні переконання письменник зберігав протягом життя, і це простежується передусім у постійних виступах на захист православ'я та заперечення унії, однак Д. Братковський писав польською мовою й загалом лояльно ставився до представників влади Речі Посполитої, на чому акцентує С. Сухарєва: «Данило Братковський, пристрасний оборонець українського православ'я, писав виключно польською та ідеалізував владу польського короля» (Сухарєва, 2013: 337). Дослідниця вважає, що, висловлюючи критику тогочасного суспільнополітичного становища, автор апелював до занепаду моральних якостей польської шляхти: «Для 
нього джерелом занепаду Речі Посполитої була не сама монархічна система, а втрата моральності польською шляхтою, від якої конструктивно мала відрізнятися шляхта українська» (Сухарєва, 2013: 337). Отже, ще одним складником інтерпретаційної моделі концепту особистості визначається апелювання письменника до польської мови, через яку відбувається зближення 3 європейським літературним простором. Значний вплив на формування світогляду, відображеного в художній концепції, мали європейські традиціï. Так, О. Турчин наголошує, що «хоча Д. Братковський активно позиціонував себе захисником православ'я, його творчість засвідчила стирання грані між «візантійсько-слов'янською» і «латинською» спільностями, великою мірою зумовленої конфесійним чинником...» (Турчин, 2017: 32). Щодо написання Д. Братковським творів польською мовою, то дослідниця зазначає, що «вибір письменниками польської мови для написання творів зумовлювався багатьма політичними та культурними обставинами, насамперед тим, що це була мова державної еліти, до якої, як читацької аудиторії, зверталися автори» (Турчин, 2015: 561).

Належність до шляхетського роду не заважала Д. Братковському бути категоричним захисником православ'я та противником політики, яку проводила Річ Посполита: «Як шляхтич і громадянин польсько-литовської держави він був носієм польської світської культури, але водночас належав до числа ревних сповідувачів православ'я. Наголошуємо, що саме релігійна свідомість (ототожнення себе часткою православного світу) була стрижнем його духовного життя» (Довбищенко, 2014: 144). У висловленнях за православну віру простежується високий рівень патріотизму й рішучості.

Одним із провідних складників, який формував концепт особистості, була освіта, зокрема навчання за кордоном, що значно вплинула на світоглядні переконання майбутнього письменника. Ймовірно, початкову освіту Д. Братковський здобув у школі при Луцькому братстві. На думку П. Кралюка, поет пізніше навчався в одному з університетів Західної Свропи: «Данило отримав непогану освіту. Очевидно, спочатку навчався у школі Луцького братства, потім - у якомусь західному університеті. Це дозволило йому зробити непогану кар'єру за умов Речі Посполитої» (Кралюк, 2015). За припущенням В. Шевчука, Д. Братковський здобув освіту в Італії, однак Д. Кулиняк вважає, що поет спочатку навчався в Києво-Могилянській академії, потім в одному з університетів Італії: «Освіту здобув у Києво-Могилянській академії. Вчився разом із С. Гурком (С. Палієм). У 1660-х рр. продовжив навчання в Італії» (Кулиняк, 2001: 87). Натомість П. Борек заперечує ці наукові концепції, зазначаючи, що Д. Братковський не навчався за кордоном (Borek, 2012).

Завдяки здобутій освіті Д. Братковському вдалося побудувати кар'єру дипломата, зокрема протягом 1667-1669 рр. він працював на посаді секретаря посольства короля Яна-Казимира в Москві. Це сприяло формуванню власної позиції щодо суспільно-політичної ситуації в державі. Власне, особистість майбутнього поета формувалася на основі виховання у православній родині, освіти, здобутої у школі Луцького братства, Києво-Могилянській академії, університеті Італії. Так, Д. Братковський був високоосвіченою людиною із чітко сформованою життєвою позицією, засуджував дії польської шляхти щодо України, стаючи на захист простого селянського населення, православ'я і висловлюючи свій національний патріотизм. Поет викривав і засуджував будь-які утиски народу з боку Речі Посполитої, загалом репрезентуючи гуманістичні настрої. На думку В. Антоновича, рішуче прагнення до боротьби й відстоювання прав православного народу було наслідком не лише суспільно-політичної ситуації, очевидцем якої був письменник, а й рисою його характеру: «Братковський не міг задовольнитися літературною діяльністю: він, за необхідності, спричиненої його характером і рівнем розвитку, повинен був вступити у фактичну боротьбу з гонителями віри отців, зневаженої дворянами, які залишили іï заради благ земних» (Антонович, 2004: 391). Вирішальним у формуванні концепту особистості Д. Братковського було загострене прагнення боротьби за свободу та справедливість, що яскраво репрезентовано однаково в біографії та творах.

Життєвий шлях Д. Братковського був тісно пов'язаний із тогочасними історичними подіями. У 1699 р. письменник збирає підписи серед представників православної шляхти Київського й Волинського воєводств для петиції із проханням до сейму, скликаного королем Августином II, надати свободу православ'ю. Однак сейм не взяв до уваги вимог, викладених у петиції, окремі представники шляхти відмовилися від своїх переконань і підтримки Д. Братковського. Становище православ'я погіршилося ще більше. Критика шляхти призвела до виступів проти нього, через що письменник змушений був переїхати до Львова. Більше того, Д. Братковський не лише продовжив свою опозиційну діяльність, а й 
зробив спробу донести свої переконання до гетьмана I. Мазепи, здійснивши поїздку до Батурина в 1700 р. і провівши секретну розмову з тогочасним керівником держави. Проте на зворотному шляху до Львова в м. Олиці Д. Братковського було затримано й ув'язнено, але врешті-решт письменника випустили на волю. Окрім того, зустріч із І. Мазепою не виправдала сподівань письменника, котрий розраховував на гетьманську допомогу. Перед ним постав вибір щодо подальших дій, на чому наголошує В. Шевчук: «Перед Д. Братковським, а може, й тією групою, яку він репрезентував, постала нова альтернатива, на яку треба було зважитися: або відмовитися від боротьби, або ж скинути шляхетську одежу і вдягти козацьку, тобто прилучитися до С. Палія, бо єдина сила, на яку він міг розраховувати, - це й були Палієві козаки» (Шевчук, 2004: 28).

Варто закцентувати на тому, що Д. Братковський, будучи представником шляхетського роду, протягом життя висловлював критику шляхти, тобто зробив вибір на користь продовження боротьби. По суті, поет виступав проти шляхти, передав свій маєток синам і в 1700-1701 рр. взяв участь у постанні С. Палія. У ході повстання Д. Братковський, переодягнувшись у простий одяг, прямував на Волинь із відозвою і листами, але під Заславом його було заарештовано та страчено в 1702 р. у Луцьку. У в’язниці поет написав заповіт, у якому зазначав, що завжди залишався вірним вірі та за неї помирає: «3 ревності дому Бога мого, для захисту святого православ'я смерть прийняти мушу» (Братковський, 2004: 379), до чого закликав своїх нащадків, також просив після його смерті роздати милостиню бідним замість поминального обіду. Показовим $\epsilon$ те, що Д. Братковському на суді було надано шанс на виправдання та відмову від свідчень про участь у повстанні, однак поет рішуче відмовився від такої можливості, наголосивши на тому, що був учасником селянського повстання С. Палія, не розкривши таємниці його проведення. Власне, така життєва позиція, якій Д. Братковський був вірним до кінця, спонукала В. Шевчука означити його життя як подвиг, а про нього самого написати як про «справжнього героя України, одного з її найсвітліших умів... одного 3 найвидатніших поетів», котрий «проніс свої ідеали через усе життя і намагався їх не переступати» (Шевчук, 2004: 31). Високо оцінив творчість Д. Братковського М. Драгоманов, який розглядав іiі на одному рівні з автором Літопису Самовидця, С. Величком, а також такими письменниками, як Г. Квітка-Основ'яненко, Т. Шевченко (Драгоманов, 1970: 185).
Суто бароковий характер інтерпретаційної моделі концепту особистості репрезентовано у збірці Д. Братковського «Світ, по частинах розглянутий», виданій у 1697 р. у Кракові з присвятою «найяснішому й непереможному Августові II, 3 Божої ласки королеві...»: «Панові, пану моєму милостивому Земні цареве 3 усіх країв світа, Несіте лаври й корони несіте!» (Братковський, 2004: 39) Однак, за переконанням В. Липинського: «Посвята зовсім розминається зі змістом книжки; в тих коротеньких віршах, що з них вона складається, яскраво змальовано сучасне життя, а на тім тлі виразно бачимо думки автора - його світогляд» (Липинський, 2013: 407). О. Бай вважає, що у збірці репрезентовано не лише світогляд поета, а й створено образ автора, який поєднує всі ідейні положення в один концептуальний центр: «Автор у Данила Братковського - це не просто вияв власного, суб'єктивного «я», яке могло стати на заваді розрізнення художньої та реальної дійсності. У поета це окремо існуючий персонаж, присутній у всіх частинах збірки «Świat po części przeyzrzany» в іпостасі голосу справедливості, найбільш вираженого авторитету» (Бай, 2013: 231). Більше того, у віршах збірки представлено світогляд поета, котрий утілював риси цілком барокової особистості, яка характеризувалася синтезом антропоцентричного та теоцентричного світоглядів: «Уже сама назва свідчить про те, що маємо справу з окремо виділеними частинами особливого поетичного світу автора, який є сполучною ланкою земних і небесних реалій» (Бай, 2012: 11).

За переконанням В. Шевчука, збірка «Світ, по частинах розглянутий» - «гостра сатира на сучасне громадянство і порядки в Речі Посполитій. Поет нещадно бичує ту Польщу, де немає місця для убогих, яка наклала на себе машкару і тільки й слухала, що мелодію дзвону грошей. Поету огидна була і держава, в якій він жив, i iii порядки» (Шевчук, 1990: 163). Окрім того, дослідник наголошує на такій рисі збірки, як універсалізм, адже автор у ній апелює до різноманітної тематики та проблематики, репрезентує синтез макро- і мікрорівня: «Загалом книгу Д. Братковського творено на основі універсальної картини світу. Тут є виходи на загальні високі теми: про Бога та диявола, рай і пекло, про простування до них, але загалом універсум розглядається на мікрорівні: пани й підлеглі, шляхта польська взагалі, а конкретніше - українська волинська; тема Речі Посполитої лише ставиться, а головне поле обсервації таки Волинь із виходами на інші землі України... Через підтексти вістить і про Козацьку 
державу, але дуже обережно» (Шевчук, 2004: 8). На універсалізмі як провідній особливості світогляду письменника зосереджує увагу О. Турчин, за переконанням якої, «у більшості творів Д. Братковський висвітлює невідповідності між бароковим ідеалом людини як гармонії божественного і земного, тобто здатність і необхідність особистості жити за законами Божими, наслідуючи ідеал Христа протиставляється тому укладу суспільного життя та моделям поведінки у ньому, які були характерними для сучасного поетові світу» (Турчин, 2011: 86).

На думку О. Яковини, збірка Д. Братковського $€$ прикладом метафізичної поезії, про що свідчить універсальний характер світоглядної парадигми, репрезентованої у збірці: «Збірка Братковського складається 3 епіграм дидактичного характеру на кшталт коротких приповідок або байок. Персонажі його поезій - це типи життєвих реалій людини, пов'язаної численними залежностями 3 громадою, станом, цілим суспільством. Такі вірші $\epsilon$ певною світоглядною системою, в якій найменша життєва подія виростає до універсального узагальнення. Людина розчинилася у створеному світі й забула про Творця. Здивування та гірка іронія автора-споглядача світу має на меті нагадати читачеві про це» (Яковина, 2010: 120).

Провідною ідеєю збірки є критика шляхти та викриття вад суспільно-політичного ладу Речі Посполитої, наголошено на необхідності боротися за правду. За переконанням автора, проблема панування у світі неправди є значним суспільним недоліком. Д. Братковський пропонує шляхи вирішення цієї ситуації, які відзначаються радикальністю й категоричністю. По суті, поет розпочав боротьбу із суспільством і був переконаний, що воно потребує змін, тож це викликало незадоволення та спротив у шляхти: «Така «хлопоманія», якої не могло вибачати шляхецьке суспільство і два віки пізніше, тим більше вражала і дратувала шляхту в XVII ст. Погляди, з якими виступає автор у своїм «Світі», відразу ставили його в ворожі відносини до загалу суспільства; 3 того ж таки часу й починається боротьба Братковського 3 сим суспільством» (Липинський, 2013: 408). Поет викриває й засуджує сваволю шляхти, котра дбає лише про особисту вигоду. Головною рисою тогочасної шляхти визначено продажність.

Окрім того, Д. Братковський репрезентує ідею про необхідність захисту бідних, засуджує суспільний устрій, у якому відсутня рівність людей. Яскраво вираженою є критика суспільства, де найбільше значення мають лише гроші й багатство, за якими оцінюється людина, а нато- мість особисті досягнення та моральні якості не беруться до уваги. Так, у вірші «Диспут убогого 3 паном» саме бідний, а не пан, наділений мудрістю та сміливістю: «Пан 3 паном здуру вели диспут довгий, Сміливо мудрий втрутився убогий» (Братковський, 2004: 49). По суті, Д. Братковський висловлює ідею про абсурдність світу, де відбулося повне знецінення справжніх моральних цінностей, втрата духовності й підміна понять, у вірші «Світ»: «Хто добрий рицар? Багач в повній мірі. Хто це - достойник? В соболім ковнірі... Хто тут філософ? Той, що дискутує. Хто ж дискутує? Хто вина купує. Хто красномовця? Хто гладко-бо править... Хто франт, хто блазень? Ледачий хто зовсім? “Бідака голий!” - отак ми голосим» (Братковський, 2004: 113). Власне, це репрезентація тогочасного суспільного устрою, де показником для визначення місця людини в суспільстві стало матеріальне. 3 метою вираження головних ідей застосовано засоби комічного, передусім сатиру, а також градацію, що твориться нанизуванням анафоричних запитань.

Окрім того, Д. Братковський подає цикл віршів «Про земських і гродських урядників, убогих, як і я», у яких звертається до різних представників суспільства (старости, хорунжого, судді, стольника, підчашого, мечника, писаря, підстарости, підсудка, намісника, війта тощо), показуючи їхнє суспільне становище. Це дає можливість репрезентувати цілісну картину тогочасного суспільства, яка набуває універсального узагальнення. Вірші написано у формі епіграм, побудованих на основі запитань і відповідей, важливим елементом є дидактичний характер. Так, В. Крекотень, аналізуючи жанрові особливості епіграми, зазначає: «Гарна епіграма повинна була дивувати і захоплювати. Цьому мали сприяти такі її якості: лаконічність (що менше в епіграмі віршових рядків, то вона досконаліша - найкраща та епіграма, до якої не можна нічого додати і від якої не можна нічого відняти); дотепність <...; особливо дотепними мають бути висновки (клаузули, аргуції, акумени, акутуми, концепти) 3 епіграматичної розповіді <...>; привабливість, яка досягається доладним розміщенням слів і літер, вправним жонглюванням поняттями і звуками... Отже, «епіграматичному письму» були притаманні різноманітні гри поняттями і словами (повтори ключових понять і слів, зіткнення антонімів)» (Крекотень, 1999: 249).

У збірці репрезентовано філософську проблему «людина - світ», що реалізується через авторське сприйняття тогочасного суспільства й розуміння сутності барокової людини, зокрема ії психологічного стану. Саме на бароковій світоглядно-худож- 
ній концепції твориться інтерпретаційна модель концепту особистості. Д. Братковський апелює до барокової ідеї про швидкоплинність і мінливість світу у вірші «Світу відміни не втямити нині», акцентуючи на його амбівалентності: «Гей, як у світі напрочуд ведеться, Здоровий, хворий, той плаче, сміється, Кричить у небо чи радо голосить, Той їсть паштети, а той хліба просить...» (Братковський, 2004: 59). Л. Ушкалов наголошує на тому, що «плинність (varietas) світу поставала питомим знаком його марності (vanitas)» (Ушкалов, 2006: 35) і репрезентувала барокову світоглядно-художню парадигму: «Мотив «марнота марнот» перебуває в самісінькому осередді ідеології української барокової поезії...» (Ушкалов, 2006: 36). Як бачимо, провідним художнім засобом у вірші Д. Братковського $є$ контраст, на основі якого вибудовується ідейна парадигма. Автор за допомогою прийому контрасту показує, що кожна людина зосереджена на собі й не помічає того, що відбувається в житті інших людей. Об'єднання людей, за переконанням Д. Братковського, дало б можливість осягнути багатовимірність і різноманітність світу: «Яка на світі трагедія-зглада, Пізнав би досить, коли б справу зладив: Тих шатних, голих, здорових, кульгавих, Голодних, п'яних, в сльозах, сміхотравних Спровадить разом до спільної хати, Що світ є дивний, змогли б розпізнати» (Братковський, 2004: 59). Так формується концепт «дивний світ», який характеризується химерністю й не піддається повному осягненню. Визначальною рисою світу визначено також минущість, що проявляється через постійні зміни, характеризується вічністю й нагадує рух по колу (вірш «Світ коло»): «Світ - коло, кажуть, колом обертає, Набуде доста, раптом утрачає. Усього збувшись, знову набуть може. Фортуни коло з рук твоїх, о Боже!» (Братковський, 2004: 279).

Барокові ідеї про швидкоплинність і минущість доповнюються темами кінечності світу (вірш «Все упадає») і смерті (вірш «Смерть»), до яких апелювали поети епохи Бароко, репрезентуючи особливості тогочасного світогляду. 3 огляду на це Д. Братковський стверджує, що все у світі є минущим, зокрема людина: «Агей, і мури, бачу, упадають, Потужні замки також здобувають. Тверде каміння перетреться в землю, Ти ж хочеш бути вічно, людське плем'я!» (Братковський, 2004: 163). Автор звертається до алегоричного образу смерті, перед якою всі рівні, переосмислюючи життя як ниву: «Гей, смерте, смерте, тягнеш нас до себе! Хотів би кожен вирватись од тебе. Багаті світу віддали б мільйони, Щоб у підземні не іти схорони... Та не купити! Як ти з сім'ям, ниво, Зіжнуть напевне, бо на те і жниво» (Братковський, 2004: 175-177).

Висновки. Отже, у творчості Д. Братковського репрезентовано інтерпретаційну модель концепту особистості, в основу якої покладено синтез антропоцентричного та теоцентричного світоглядів. На основі аналізу біографії та творчої спадщини письменника, представлених у збірці «Світ, по частинах розглянутий», обгрунтовано апелювання автора передусім до художньої образності та світогляду епохи Бароко, що вплинуло на бароковий характер інтерпретаційної моделі концепту особистості. Осмислення свободи трактується письменником через національне й особисте розуміння, позначене патріотизмом, і характеризується антропоцентричним спрямуванням. Історичні події та сприйняття тогочасного суспільства позначені активною національною позицією Д. Братковського. Авторське розуміння віри та заперечення унії свідчать про теоцентричне спрямування світоглядних орієнтирів особистості. Цілісний аналіз концептуальних положень збірки «Світ, по частинах розглянутий» дає можливість виокремити такі основні складники концепту особистості, як шляхетське походження письменника, виховання у православній родині, тогочасні історичні події та становище українського народу, освіта в Києво-Могилянській академії й університетах Західної Європи, а також барокова світоглядна парадигма, що свідчить про поєднання європейських і національних традицій у творчій спадщині митця.

\section{СПИСОК ВИКОРИСТАНИХ ДЖЕРЕЛ}

1. Антонович В. Б. Даниил Братковский. Братковський Д. Б. Світ, по частинах розглянутий. Луцьк : Видавництво обласної друкарні, 2004. С. 389-398.

2. Бай О. С. Особливості часопростору поезії Данила Братковського. Київські полоністичні студії. 2013. Т. 22. C. 230-232.

3. Бай О. С. Поміж земним та небесним: рецепція поетичного світу Данила Братковського. Украӥна та Польща: минуле, сьогодення, перспективи. Луцьк : Волинський національний університет ім. Лесі Українки, 2012. Т. 1. C. $11-13$.

4. Borek P. Nowe materiały do biografii Daniela Bratkowskiego. Od Kijowa do Rzymu. Z dziejów stosunków Rzeczypospolitej ze Stolica Apostolska i Ukrainą. Białystok: Instytut Badań na Dziedzictwem Kulturowym Europy, 2012. C. $1103-1118$.

5. Братковський Д. Б. Світ, по частинах розглянутий. Луцьк : Видавництво обласної друкарні, 2004. 463 с. 
6. Возняк М. С. Поет шляхтич-хлопоман кінця XVII віку. Історія української літератури. Львів : Світ, 1994. T. 2. C. $54-55$.

7. Довбищенко М. В. Данило Братковський в суспільно-релігійному житті Волині останньої третини XVII початку XVIII ст. Дрогобицький краєзнавчий збірник. 2014. № 17. С. 143-153.

8. Драгоманов М. П. Література російська, великоруська, українська і галицька. Літературно-публіцистичні прачі : у 2 т. Київ : Наукова думка, 1970. Т. 1. С. 80-220.

9. Кралюк П. М. Образ світу в поезії Данила Братковського. URL: http://www.volynnews.com/blogs/ ukrayintsiambrakuye-filosofiyi-rozumu-/obraz-svitu-v-poeziyi-danyla-bratkovskoho/.

10. Крекотень В. І. Українська книжна поезія середини XVII ст. Вибрані пращі. Київ : Обереги, 1999. С. $240-272$.

11. Кулиняк Д. І. Братковський Данило Богданович. Києво-Могилянська академія в іменах XVII-XVIII cm. / ред. В. С. Брюховецький. Київ : Академія, 2001. С. 87.

12. Липинський В. К. Данило Братковський - суспільний діяч і письменник кінця XVII століття. В 'ячеслав Липинський та його доба / упоряд. Т. Осташко, Ю. Терещенко. Київ : Темпора, 2013. Т. 3. С. 403-415.

13. Сухарєва С. В. Феномен польськомовної літератури в давньому українському письменстві. Київські полоністичні студіï. 2013. Т. 22. С. 335-337.

14. Турчин О. В. Барокова модель діалогу зі світом у творчості Данила Братковського : дис. ... канд. філол. наук : 10.01.01. Київ : Національний педагогічний університет імені М. П. Драгоманова, 2017. 225 с.

15. Турчин О. В. Данило Братковський - поет українсько-польського культурного помежів'я епохи бароко. Сучасні літературознавчі студіï. 2015. № 12. С. 559-568.

16. Турчин О. В. Проблема особистісної та національної ідентичності героїв творів Д. Братковського у дискурсі барокової концепції універсалізму. Наукові праці Чорноморського держсавного університету імені Петра Могили комплексу «Києво-Могилянська академія». 2011. Т. 170. № 158. С. 85-89.

17. Ушкалов Л. В. Есеї про українське бароко. Київ : Факт - Наш час, 2006. 284 с.

18. Шевчук В. О. Подвиг Данила Братковського. Із вериин та низин: Книжка ичікавих фактів із історії української літератури. Київ : Дніпро, 1990. С. 162-164.

19. Шевчук В. О. Про Данила Братковського - поета й людину. Братковський Д. Б. Світ, по частинах розглянутий. Луцьк : Видавництво обласної друкарні, 2004. С. 5-32.

20. Яковина О. П. Метафізика в поезії: Україна XVII ст. Київ : Інститут літератури імені Тараса Шевченка, 2010. 202 c.

\section{REFERENCES}

1. Antonovych V. B. Danyyl Bratkovskyi [Daniil Bratkovsky]. Bratkovskyi D. B. Svit, po chastynakh rozghlianutyi. Lutsk: Vydavnytstvo oblasnoi drukarni, 2004. pp. 389-398. [in Russian].

2. Bai O. S. Osoblyvosti chasoprostoru poezii Danyla Bratkovskoho [Peculiarities of the space-time of Danylo Bratkovsky's poetry]. Kyivski polonistychni studii. 2013. T. 22. pp. 230-232. [in Ukrainian].

3. Bai O. S. Pomizh zemnym ta nebesnym: retseptsiia poetychnoho svitu Danyla Bratkovskoho. Ukraina ta Polshcha: mynule, sohodennia, perspektyvy [Between the earthly and the heavenly: the reception of the poetic world of Danylo Bratkovsky]. Lutsk: Lesya Ukrainka Volyn National University, 2012. T. 1. pp. 11-13. [in Ukrainian].

4. Borek P. Nowe materiały do biografii Daniela Bratkowskiego [New materials for the biography of Daniel Bratkowski]. Od Kijowa do Rzymu. Z dziejów stosunków Rzeczypospolitej ze Stolicą Apostolską i Ukrainą. Białystok: Instytut Badań na Dziedzictwem Kulturowym Europy, 2012. pp. 1103-1118. [in Polish].

5. Bratkovskyi D. B. Svit, po chastynakh rozghlianutyi [The world, in parts considered]. Lutsk: Vydavnytstvo oblasnoi drukarni, 2004. 463 p. [in Ukrainian].

6. Vozniak M. S. Poet shliakhtych-khlopoman kintsia XVII viku [The poet as a nobleman-thief of the end of the XVII century]. Istoriia ukrainskoi literatury. Lviv: Svit, 1994. T. 2. pp. 54-55. [in Ukrainian].

7. Dovbyshchenko M. V. Danylo Bratkovskyi v suspilno-relihiinomu zhytti Volyni ostannoi tretyny XVII - pochatku XVIII st. [Danilo Bratkovsky in the socio-religious life of Volhynia in the last third of the XVII - early XVIII centuries]. Drohobytskyi kraieznavchyi zbirnyk. 2014. № 17. pp. 143-153. [in Ukrainian].

8. Drahomanov M. P. Literatura rosiiska, velykoruska, ukrainska i halytska [Russian, Great Russian, Ukrainian and Galician literature]. Literaturno-publitsystychni pratsi: u 2 t. Kyiv: Naukova dumka, 1970. T. 1. pp. 80-220. [in Ukrainian].

9. Kraliuk P. M. Obraz svitu v poezii Danyla Bratkovskoho [The image of the world in the poetry of Danylo Bratkovsky]. URL: http://www.volynnews.com/blogs/ukrayintsiambrakuye-filosofiyi-rozumu-/obraz-svitu-v-poeziyidanyla-bratkovskoho/ [in Ukrainian].

10. Krekoten V. I. Ukrainska knyzhna poeziia seredyny XVII st. [Ukrainian book poetry of the middle of the XVII century]. Vybrani pratsi. Kyiv: Oberehy, 1999. pp. 240-272. [in Ukrainian].

11. Kulyniak D. I. Bratkovskyi Danylo Bohdanovych. Kyievo-Mohylianska akademiia v imenakh XVII-XVIII st. [Bratkovsky Danilo Bogdanovich] / Red. V.S. Briukhovetskyi. Kyiv: Akademiia, 2001. pp. 87. [in Ukrainian].

12. Lypynskyi V. K. Danylo Bratkovskyi - suspilnyi diiach i pysmennyk kintsia XVII stolittia [Danilo Bratkovsky as a public figure and writer of the late XVII century]. Viacheslav Lypynskyi ta yoho doba / Uporiad. T. Ostashko, Yu. Tereshchenko. Kyiv: Tempora, 2013. T. 3. pp. 403-415. [in Ukrainian].

13. Sukharieva S. V. Fenomen polskomovnoi literatury v davnomu ukrainskomu pysmenstvi [The phenomenon of Polishlanguage literature in ancient Ukrainian literature]. Kyivski polonistychni studii. 2013. T. 22. pp. 335-337. [in Ukrainian]. 
14. Turchyn O. V. Barokova model dialohu zi svitom u tvorchosti Danyla Bratkovskoho: dys. ... kand. filol. nauk: 10.01 .01 [Baroque model of dialogue with the world in the works of Danylo Bratkovsky: dissertation for the degree of Candidate of Philological Sciences in the specialty 10.01.01]. Kyiv: National Pedagogical Dragomanov University, 2017.225 p. [in Ukrainian].

15. Turchyn O. V. Danylo Bratkovskyi - poet ukrainsko-polskoho kulturnoho pomezhivia epokhy baroko [Danylo Bratkovsky as a poet of the Ukrainian-Polish cultural frontier of the Baroque epoch]. Suchasni literaturoznavchi studii. 2015. № 12. pp. 559-568. [in Ukrainian].

16. Turchyn O. V. Problema osobystisnoi ta natsionalnoi identychnosti heroiv tvoriv D. Bratkovskoho u dyskursi barokovoi kontseptsii universalizmu [The problem of personal and national identity of the heroes of D. Bratkovsky's works in the discourse of the baroque concept of universalism]. Naukovi pratsi Chornomorskoho derzhavnoho universytetu imeni Petra Mohyly kompleksu “Kyievo-Mohylianska akademiia”. 2011. T. 170. № 158. pp. 85-89. [in Ukrainian].

17. Ushkalov L. V. Esei pro ukrainske baroko [Essays about the Ukrainian Baroque]. Kyiv: Fakt - Nash chas, 2006. 284 p. [in Ukrainian].

18. Shevchuk V. O. Podvyh Danyla Bratkovskoho [The feat of Danylo Bratkovsky]. Iz vershyn ta nyzyn: Knyzhka tsikavykh faktiv iz istorii ukrainskoi literatury. Kyiv: Dnipro, 1990. pp. 162-164. [in Ukrainian].

19. Shevchuk V. O. Pro Danyla Bratkovskoho - poeta y liudynu [About Danylo Bratkovsky as a poet and a person]. Bratkovskyi D. B. Svit, po chastynakh rozghlianutyi. Lutsk: Vydavnytstvo oblasnoi drukarni, 2004. pp. 5-32. [in Ukrainian].

20. Yakovyna O. P. Metafizyka v poezii: Ukraina XVII st. [Metaphysics in poetry: Ukraine of the XVII century]. Kyiv: Instytut literatury imeni Tarasa Shevchenka, 2010. 202 p. [in Ukrainian]. 